Pak. J. Sci. Ind. Res. Ser. A: Phy. Sci. 201154 (1) 14-18

\title{
Effects of Storage and Packaging Materials on Some Physicochemical Properties and Sensory and Microbiological Parameters of Pineapple Juice (Ananas comosus)
}

\author{
Itunnu Olubunmi Shakpo a ${ }^{\mathrm{a}}$ and Jacob Olalekan Arawande ${ }^{\mathrm{b} *}$ \\ a'Department of Food Science and Technology, Rufus Giwa Polytechnic, \\ P.M.B. 1019, Owo, Ondo State, Nigeria \\ bDepartment of Science Laboratory Technology, Rufus Giwa Polytechnic, \\ P.M.B. 1019, Owo Ondo State, Nigeria
}

(received February 12, 2010; revised August 23, 2010; accepted September 3, 2010)

\begin{abstract}
Physicochemical, microbiological and sensory parameters of concentrated pineapple juice stored in cans and glass bottles were studied over a period of ten weeks. There was slight increase in $\mathrm{pH}$ from 4.2 to 4.7 and to 4.8 and decrease in titratable acidity from 8.1 to 5.1 and to $4.6 \mathrm{mg} / 100 \mathrm{~mL}$, whereas total solids (\%) decreased from 76.23 to $65.47 \%$ and to $60.38 \%$ in canned and bottled pineapple concentrates, respectively. Over $90 \%$ loss of Vitamin C was observed, with the bottled samples retaining more Vitamin $\mathrm{C}$ than the canned samples. The microbial counts ranged from $2.0 \times 10^{3}$ to $2.4 \times 10^{4} \mathrm{cfu} / \mathrm{mL}$ whereas fungi and mesophilic bacteria, were not detected to $6 \times 10^{3} \mathrm{cfu} / \mathrm{mL}$. Freshly prepared single strength juices of pineapple were better in terms of taste and colour, while the bottled reconstituted juice concentrate competed favourably with the fresh one in colour. The canned samples lost their colours within 10 weeks of storage. The glass bottled samples had a characteristic desirable aroma. Thus concentrated juice in glass bottles stored at room temperature enhanced the keeping quality of the juice and compared more favourably with the fresh juice than the canned concentrated juice.
\end{abstract}

Keywords: pineapple juice, packaging materials, physicochemical properties, sensory qualities, microbiological quality, storage

\section{Introduction}

Fruits are common food materials, which contribute micronutrients (vitamins and minerals) and natural soluble sugars for energy to support human nutrition (Ihekoronye and Ngoddy, 1985).

Juice is obtained from fruits e.g., orange, pineapples, apple, grape etc., and concentrates can be prepared by partial evaporation of moisture from the juices which are likely to have a longer shelf life than the juices due to lower moisture content (Takahashi et al., 2000)

Pineapple (Ananas comosus) is one of the most common non-citrus tropical and sub-tropical fruits. It has pleasant flavour and acceptable taste and is a very rich source of vitamin $\mathrm{C}$ and organic acids. Pineapple contains high level of sugars and other carbohydrates and is, therefore, a major source of dietary fibre and enzymes and can serve as digestion aids (Takahashi, et al., 2000). Pineapple is a member of the Bromiliaceae family (Medina and Garcia, 2005) and is the second largest harvest of importance after bananas, contributing over $20 \%$ of the world

*Author for correspondence: E-mail: joawande1@yahoo.com production of tropical fruits (COVECA, 2002). Nearly $70 \%$ of pineapple is consumed as fresh fruit in the producing countries. Thailand, Philippines, Brazil and China are the main pineapple producers in the world, supplying $50 \%$ of the total output (FAO, 2004). Other important producers include India, Nigeria, Kenya, Indonesia, Mexico and Costa Rica that account for the remaining $50 \%$.

Pineapple, as a plant is put to a number of uses. One of the best known uses of pineapple juice is as a diuretic in the ailments of kidneys, bladder and prostate. Due to the fibre content of the pulp, pineapple prevents constipation and regularizes the intestinal flora (FAO, 2004). Furthermore, there is evidence of pineapple being an appetite reducer, heat protector and an aid in treatment of fever and sore throats, mouth aches and inflammation. Lightly boiled ground pineapple can be used to clean infected wounds because it eliminates dead tissues without affecting live tissues, acts as a disinfectant and accelerates cicatrisation (Mundogar, 2004).

Unfortunately, this fruit is seasonal, highly perishable and prone to high post-harvest losses. Post-harvest losses 
occur in fruits during transportation, storage and while waiting to be processed. Pineapples, after harvesting are still physiologically active. Deterioration of fruit can result from physical factors such as bruises, action of their own enzymes (proteolytic enzyme), microbial action, or combination of these agents. Extracting and concentrating the juice reduces the losses by enhancing the keeping qualities thereby making it available all the year round (Verma and Joshi, 2000).

Losses in pineapple during air transport can be minimized by careful handling. Mechanical damage includes bruising or puncturing caused by poor handling, dropping or abrasion resulting in localized softening and development of secondary microbial infections. Protective measures are required throughout the handling stages to minimize fruit damage. (GeoCoppens and Ferla, 2000).

Canning is a method of food preservation which involves subjecting food materials in cans to elevated temperature for the purposes of eliminating both pathogenic and spoilage organisms and hermetically sealing the cans to avoid external influence from the environment. Bottling is also a method of preservation which employs the use of sterile glass bottles with lids in food packaging.

Chemical composition and microbial profile of a food are the most important parameters in determining the overall quality of that food. Changes in these parameters which occur during preparation and subsequent storage are indices of the suitability or otherwise of the product for consumption. Although, food preservation is necessary, the maintenance of the nutrients in the food is also of utmost importance. Pineapples is known to be the best source of vitamin $\mathrm{C}$, a major portion of which is lost during storage at room temperature (Egidio et al., 2009).

Previous works on pineapple showed that it contains 81.2 to $86.2 \%$ moisture and $13-19 \%$ total solids of which sucrose, glucose and fructose are the main components. Carbohydrates are up to $85 \%$ of the total solids whereas, fibre makes upto 2-3\%; citric acid is the most abundant organic acid. Pulp has very low ash content, nitrogen compounds and lipids (0.1\%); $25-30 \%$ of nitrogenous compounds are true proteins. Out of this proportion, $80 \%$ has proteolytic activity due to a protease known as Bromelain (Dull, 1971). Utilization of by-products from pineapple culture, canning and juice extraction has been encouraged for feed production (GeoCoppens and Ferla, 2000).
The objectives of this research work were to extract and concentrate pineapple juice in the form of thick slurry, store it in tin cans and glass bottles and examine the effects of storage containers on the physico-chemical properties, sensory and microbiological qualities of the juice stored over a period of ten weeks.

\section{Materials and Methods}

Pineapple fruits, used for this research work, were purchased from a renowned market called "Oja Koko” in Owo Local Government area, Ondo State, Nigeria. The juice was extracted from the fruits following the procedure (Fig. 1) described by Ihekoronye and Ngoddy (1985). The juice was concentrated to $71 \%$ brix using a water bath $\left(40^{\circ} \mathrm{C}\right)$ at a temperature slightly above the room temperature. The concentrate was divided into two parts; one part was placed in tin cans(laminated) while the other, in glass bottles of equal capacity. The juice was stored inside a cupboard (dark) at room temperature of $28^{\circ} \mathrm{C}$ on an average. The physico-chemical properties, sensory qualities and microbial content of pineapple juice and concentrate were determined every two week for a period of ten weeks.

Determination of the physicochemical properties of the pineapple juice. The physicochemical properties determined were $\mathrm{pH}$, brix, total solids, specific gravity, total titratable acidity and vitamin $\mathrm{C}$ content. The $\mathrm{pH}$ of fresh pineapple juice as well as the concentrated juice was determined using $\mathrm{pH}$ meter. Brix was determined using Abbe refractometer. Total solids, specific gravity, total titratable acidity and vitamin $\mathrm{C}$ were determined using standard methods (AOAC, 2005).

\section{Sensory evaluation of pineapple juice concentrate.} Sensory evaluation based on taste, colour and aroma was carried out as described by Larmond (1982) using a team of 10 taste panelists for each set of samples. Score of each panelist was reflected on a nine point Hedonic scale ranging from nine (like extremely) to one (dislike extremely). The result obtained was subjected to statistical analysis of variance and means were calculated using Duncan's Post Hoc. Test.

Microbiological analyses of pineapple juice concentrate. The media used in carrying out the microbial count of the samples were MacConkey agar (MA) and potato dextrose agar (PDA) for viable plate counts of mesophilic bacteria and yeast and mould, respectively. The medium was prepared according to the method described by Franzetti and Galli (1999). 
Raw materials (pineapple fruit)

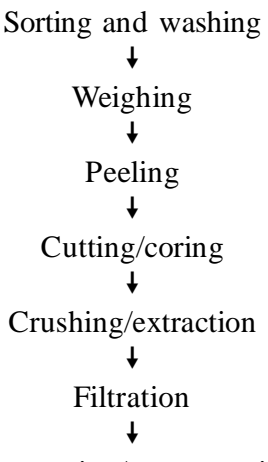

Evaporation/concentration

$\downarrow$ Sterilization of cans and bottles<smiles>[111In][131In]</smiles>

$\rightarrow$ Bottling

Lidding/clinching

$\downarrow$

Exhausting/vacuuming<smiles>[123IH]</smiles>

Sealing

$\downarrow$

Cooling

Juice concentrate

Fig. 1. Flow chart for the production of pineapple juice concentrate.

\section{Results and Discussion}

From the result of various analyses carried out during ten weeks of storage, several data trends were observed. The results presented in Table 1 are a combination of trends seen in the experiments (on canned and bottled pineapple concentrates). The means and standard deviations are based on triplicate analyses of each sample from individual container per storage condition.

Table 1 shows some physicochemical properties of pineapple juice and concentrate stored in tin cans and glass bottles for a period of ten weeks. The fresh pineapple juice had a pH of $3.70 \pm 0.10,{ }^{0} \mathrm{brix}$ of $12.20 \pm 0.427 \%$, total titratable acidity of $1.38 \pm 0.03 \mathrm{~g} /$ $100 \mathrm{~mL}$ citric acid, vitamin C content of $153.3 \pm 0.4 \mathrm{mg} /$ $100 \mathrm{~mL}$, total solids $10.11 \pm 0.11 \%$ and specific gravity of $1.21 \pm 0.033$. This is consistent with the findings of Nelson (2005) who obtained $12.8 \%$ brix, and 0.724 g/ $100 \mathrm{~mL}$ total acidity. The concentrated juice had a $\mathrm{pH}$ of $4.20 \pm 0.10,{ }^{0}$ Brix of $71.01 \pm 0.115 \%$, total titratable acidity of $8.17 \pm 0.148 \mathrm{~g} / 100 \mathrm{~mL}$ citric acid, vitamin C content of $781.94 \pm 0.051 \mathrm{mg} / 100 \mathrm{~mL}$, total solids of $76.23 \pm 0.252 \%$ and specific gravity of $1.25 \pm 0.104$. It was observed that all these parameters (except $\mathrm{pH}$ ) decreased as the progress of storage period increased in both the canned and bottled concentrates. The $\mathrm{pH}$, brix and vitamin $\mathrm{C}$ of bottled concentrate were relatively higher than that of the bottled concentrate while

Table1. Some pysicochemical properties of pineapple juice and concentrate stored in tin cans and glass bottles for a period of ten weeks

\begin{tabular}{|c|c|c|c|c|c|c|c|}
\hline $\begin{array}{l}\text { Time } \\
\text { (weeks) }\end{array}$ & $\begin{array}{l}\text { Pineapple juice } \\
\text { sample }\end{array}$ & ${ }^{*} \mathrm{pH}$ & $\begin{array}{l}* \text { Brix } \\
(\%)\end{array}$ & $\begin{array}{l}\text { *Titratable } \\
\text { acidity } \\
\text { (g/100 mL } \\
\text { citric acid) }\end{array}$ & $\begin{array}{l}\text { *Vitamin C } \\
(\mathrm{mg} / 100 \mathrm{~mL})\end{array}$ & $\begin{array}{l}\text { Total } \\
\text { solid } \\
(\%)\end{array}$ & $\begin{array}{l}\text { Specific } \\
\text { gravity }\end{array}$ \\
\hline \multirow[t]{4}{*}{0} & Fresh juice & $3.70 \pm 0.10$ & $12.20 \pm 0.43$ & $1.38 \pm 0.03$ & $153.30 \pm 0.40$ & $10.11 \pm 0.11$ & $1.21 \pm 0.03$ \\
\hline & Concentrated Juice & $4.20 \pm 0.10$ & $71.01 \pm 0.12$ & $8.17 \pm 0.15$ & $781.94 \pm 0.05$ & $76.23 \pm 0.25$ & $1.25 \pm 0.10$ \\
\hline & Canned concentrate & $4.20 \pm 0.09$ & $71.30 \pm 0.61$ & $8.17 \pm 0.02$ & $780.91 \pm 0.42$ & $76.23 \pm 0.33$ & $1.31 \pm 0.01$ \\
\hline & Bottled concentrate & $4.20 \pm 0.07$ & $70.92 \pm 0.38$ & $8.17 \pm 0.02$ & $781.94 \pm 0.05$ & $76.23 \pm 0.44$ & $1.31 \pm 0.01$ \\
\hline \multirow[t]{2}{*}{2} & Canned concentrate & $4.40 \pm 0.10$ & $63.42 \pm 0.29$ & $7.64 \pm 0.04$ & $141.03 \pm 0.15$ & $74.42 \pm 0.42$ & $1.34 \pm 0.14$ \\
\hline & Bottled concentrate & $4.50 \pm 0.10$ & $66.30 \pm 0.48$ & $7.62 \pm 0.02$ & $177.66 \pm 0.60$ & $70.37 \pm 0.07$ & $1.33 \pm 0.03$ \\
\hline \multirow[t]{2}{*}{4} & Canned concentrate & $4.53 \pm 0.15$ & $63.29 \pm 0.19$ & $7.04 \pm 0.02$ & $72.99 \pm 0.43$ & $71.41 \pm 0.01$ & $1.32 \pm 0.01$ \\
\hline & Bottled concentrate & $4.60 \pm 0.10$ & $67.33 \pm 0.15$ & $6.94 \pm 0.06$ & $80.29 \pm 0.10$ & $66.39 \pm 0.09$ & $1.33 \pm 0.01$ \\
\hline \multirow[t]{2}{*}{6} & Canned concentrate & $4.57 \pm 0.06$ & $62.92 \pm 0.52$ & $6.90 \pm 0.02$ & $34.16 \pm 0.18$ & $68.39 \pm 0.09$ & $1.30 \pm 0.05$ \\
\hline & Bottled concentrate & $4.60 \pm 0.20$ & $66.87 \pm 0.11$ & $6.58 \pm 0.03$ & $41.13 \pm 0.54$ & $63.44 \pm 0.48$ & $1.30 \pm 0.04$ \\
\hline \multirow[t]{2}{*}{8} & Canned concentrate & $4.63 \pm 0.06$ & $63.07 \pm 0.07$ & $6.37 \pm 0.03$ & $12.06 \pm 0.05$ & $66.14 \pm 0.09$ & $1.31 \pm 0.04$ \\
\hline & Bottled concentrate & $4.70 \pm 0.48$ & $66.25 \pm 0.25$ & $6.22 \pm 0.026$ & $16.03 \pm 0.10$ & $61.82 \pm 0.26$ & $1.28 \pm 0.02$ \\
\hline \multirow[t]{2}{*}{10} & Canned concentrate & $4.70 \pm 0.10$ & $62.50 \pm 0.33$ & $5.11 \pm 0.11$ & $7.02 \pm 0.05$ & $65.47 \pm 0.07$ & $1.31 \pm 0.01$ \\
\hline & Bottled concentrate & $4.80 \pm 0.06$ & $66.33 \pm 0.14$ & $4.61 \pm 0.03$ & $13.02 \pm 0.03$ & $60.38 \pm 0.07$ & $1.29 \pm 0.09$ \\
\hline
\end{tabular}

$*=$ mean value \pm standard deviation of triplicate determinations. 
the reverse trend was noticed for titratable acidity and total solid over ten week storage period. However, the parameters of fresh juice were much lower than that of the concentrated juice (canned and bottled concentrates). This can be attributed to the fact that the concentrated juice contains reduced moisture content (Montero-Calderon et al., 1998).

Over the period of storage, the range values of $\mathrm{pH},{ }^{0} \mathrm{Brix}$, total titratable acidity, Vitamin $\mathrm{C}$ and total solid content of canned concentrate were 4.20-4.70, 62.50-71.30\%, 5.11-8.17 g/100 mL citric acid, $7.02-780.91 \mathrm{mg} / 100$ $\mathrm{mL}$ and $65.47-76.23 \%$, respectively, while that of the bottled concentrate were $4.20-4.80,66.33 \%-70.92 \%$, 4.61-8.17 mg/100 mL citric acid, $13.02-781.94 \mathrm{mg} / 100$ $\mathrm{mL}$ and $60.38-76.23 \%$, respectively.

There was a sharp decrease in the brix content of pineapple juice between the initial time of production and the second week of storage (week 2) while it was relatively steady during the remaining storage period with slight difference. Slight increase in $\mathrm{pH}$ with the cor-responding slight decrease in the titratable acidity of pineapple juice in both the containers was observed during the storage which is in agreement with the findings of Montero-Calderon et al. (2008). Total solid and Vitamin $C$ were also observed to decrease with time. Vitamin C remarkably decreased to the tune of more than $90 \%$ loss, while the total solids slightly decreased over the storage period. Specific gravity of the juice was relatively stable throughout the period of storage with negligible difference.

The colour of the juice concentrate reduced with storage period; the juice concentrates being acidic reacted with the cans and resulted in darkening of the colour. Despite the transparency of glass bottles, the sample in bottle containers competed favourably with the fresh samples in terms of colour. This may be due to the fact that the samples were not exposed to light; exposure of juice to light naturally denatures it. It was also observed that the bottled samples retained more Vitamin $\mathrm{C}$ which is the major nutrient in juices than the canned samples.

Table 2 depicts the mean score of sensory qualities. It was observed that there were significant differences in terms of taste, colour and aroma among the samples examined. However, fresh juices were mostly preferred to the reconstituted juices followed by the bottled concentrate, while the canned concentrates were ranked the least in term of colour.
Table 2. Sensory quality of pineapple fresh juice and concentrate samples

\begin{tabular}{|c|c|c|c|c|}
\hline $\begin{array}{l}\text { Time } \\
\text { (weeks) }\end{array}$ & Attributes & Fresh juice & $\mathrm{CPC}$ & BPC \\
\hline \multirow{3}{*}{0} & Taste & $5.8^{\mathrm{b}}$ & $5.5^{b}$ & $5.3^{b}$ \\
\hline & Colour & $7.4^{\mathrm{a}}$ & $5.8^{\mathrm{b}}$ & $6.9^{\mathrm{ab}}$ \\
\hline & Aroma & $6.3^{\mathrm{b}}$ & $5.5^{\mathrm{b}}$ & $5.5^{\mathrm{b}}$ \\
\hline \multirow{3}{*}{2} & Taste & $6.2^{\mathrm{a}}$ & $4.2^{\mathrm{b}}$ & $4.7^{\mathrm{b}}$ \\
\hline & Colour & $6.2^{\mathrm{a}}$ & $5.9^{\mathrm{a}}$ & $5.7^{\mathrm{a}}$ \\
\hline & Aroma & $7.5^{\mathrm{a}}$ & $6.5^{\mathrm{a}}$ & $5.8^{\mathrm{a}}$ \\
\hline \multirow{3}{*}{4} & Taste & $7.8^{\mathrm{a}}$ & $6.1^{\mathrm{b}}$ & $6.1^{\mathrm{b}}$ \\
\hline & Colour & $7.0^{\mathrm{b}}$ & $6.8^{\mathrm{b}}$ & $8.2^{\mathrm{a}}$ \\
\hline & Aroma & $7.1^{\mathrm{b}}$ & $6.4^{\mathrm{b}}$ & $6.2^{\mathrm{b}}$ \\
\hline \multirow{3}{*}{6} & Taste & $6.7^{\mathrm{a}}$ & $5.1^{\mathrm{b}}$ & $4.8^{\mathrm{b}}$ \\
\hline & Volour & $6.6^{\mathrm{a}}$ & $7.1^{\mathrm{a}}$ & $6.8^{\mathrm{a}}$ \\
\hline & Aroma & $7.9^{\mathrm{a}}$ & $6.2^{\mathrm{b}}$ & $5.8^{\mathrm{b}}$ \\
\hline \multirow{3}{*}{8} & Taste & $8.0^{\mathrm{a}}$ & $5.8^{\mathrm{b}}$ & $5.5^{\mathrm{b}}$ \\
\hline & Colour & $7.9^{\mathrm{a}}$ & $6.4^{\mathrm{b}}$ & $6.7^{\mathrm{b}}$ \\
\hline & Aroma & $7.2^{\mathrm{a}}$ & $5.6^{\mathrm{b}}$ & $6.2^{\mathrm{b}}$ \\
\hline \multirow{3}{*}{10} & Taste & $5.3^{\mathrm{b}}$ & $4.3^{\mathrm{b}}$ & $4.1^{\mathrm{b}}$ \\
\hline & Colour & $7.8^{\mathrm{a}}$ & $6.4^{\mathrm{b}}$ & $6.4^{\mathrm{b}}$ \\
\hline & Aroma & $4.9^{\mathrm{b}}$ & $6.0^{\mathrm{ab}}$ & $6.2^{\mathrm{ab}}$ \\
\hline
\end{tabular}

Means with different superscripts in a row for each week are subscript significantly different $(\mathrm{P}=0.05)$; $\mathrm{CPC}=$ canned pineapple concentrate; $\mathrm{BPC}=$ bottled pineapple concentrate.

Table 3. Microbial counts of pineapple juice and concentrate

\begin{tabular}{llll}
\hline \hline $\begin{array}{l}\text { Time } \\
\text { (weeks) }\end{array}$ & Pineapple sample & $\begin{array}{l}\text { Fungi } \\
\text { (cfu/mL) }\end{array}$ & $\begin{array}{l}\text { Mesophilic } \\
\text { bacteria } \\
\text { (cfu/mL) }\end{array}$ \\
\hline \multirow{3}{*}{$\begin{array}{l}\text { Fresh juice } \\
\text { Concentrated juices }\end{array}$} & $2.4 \times 10^{4}$ & $5 \times 10^{3}$ \\
& Canned concentrate & $2.0 \times 10^{3}$ & $1 \times 10^{3}$ \\
& Bottled concentrate & $2.0 \times 10^{3}$ & $1 \times 10^{3}$ \\
2 & Canned concentrate & $6.0 \times 10^{3}$ & $2.0 \times 10^{3}$ \\
& Bottled concentrate & $8.0 \times 10^{3}$ & $4.0 \times 10^{3}$ \\
4 & Canned concentrate & $1.2 \times 10^{4}$ & $3.0 \times 10^{3}$ \\
& Bottled concentrate & $2.0 \times 10^{4}$ & $6.0 \times 10^{3}$ \\
6 & Canned concentrate & $8.0 \times 10^{3}$ & $2.0 \times 10^{3}$ \\
& Bottled concentrate & $2.0 \times 10^{4}$ & $6.0 \times 10^{3}$ \\
8 & Canned concentrate & $6.0 \times 10^{3}$ & $\mathrm{ND}$ \\
& Bottled concentrate & $1.4 \times 10^{4}$ & $2.0 \times 10^{3}$ \\
10 & Canned concentrate & $4.0 \times 10^{3}$ & $\mathrm{ND}$ \\
& Bottled concentrate & $1.0 \times 10^{4}$ & $2.0 \times 10^{3}$ \\
\hline \hline
\end{tabular}

$\mathrm{ND}=$ not detected. 
Table 3 documents the microbial counts of pineapple fresh juice and concentrate. The viable plate counts of mesophilic bacteria, yeast and mould were reduced with concentration process. However, they increased with storage up to the $4^{\text {th }}$ and the $6^{\text {th }}$ week and later started decreasing. The predominant members were mould and yeast; this is due to the fact that the juice concentrate is acidic (Ihekoronye and Ngoddy, 1985). Bacterial contamination may be due to poor handling during processing. In the canned samples, the microbial load was less than that in the bottled samples due to the anaerobic condition in the cans. In any case, the reconstituted juices from the concentrates are microbiologically fit for consumption since the microbial loads were within tolerable limits for human consumption.

\section{Conclusion}

Juice concentrates stored in glass bottles had better physicochemical and sensory qualities; due to inert nature of glass it prevented certain reactions. However, concentrated fruit juices in cans contained less microbial load but with unacceptable colour. Conclusively, pineapple juice and concentrate stored in glass bottle retained more nutrients and is preferred to the juice stored in cans in terms of colour, taste and Vitamin C retention.

\section{References}

AOAC 2005. Official Methods of Analysis, $17^{\text {th }}$ edition, Association of Official Analytical Chemist. Washington D.C., USA.

COVECA 2002. Comision Veracruzana de Comercializacion Agropecuaria. Gobierno del Estado de Veracruz, Mexico.

Dull, G.G. 1971. The pineapple: general. In: The Biochemistry of Fruits and Their Products, A.C. Hulme (ed.), vol. 2, pp. 303-324, Academic Press, New York, USA.

Egidio, V.D., Sinelli, N., Limbo, S., Torri, L., Franzetti, L., Casivagi, E. 2009. Evaluation of shelf life of freshcut pineapple using FT-NIR and FT-IR Spectroscopy. Postharvest Biology and Technology, 54: 87-92.

FAO 2004. Pineapple Postharvest Operations http:// www.fao.org/livestock/agap/frg/afris/espanol, Date retrieved 10/7/2009.

Franzetti, L., Galli, A. 1999. Microbial quality indicators in minimally processed carrot. Annali di Microbiologia ed Enzimologica, 49: 137-144.

GeoCoppens, D., Ferla, D.L. 2000. Fruits from America - An Ethnobotanical Inventory. IPGRI and CIRAD. www.cefe.cnrs.fr/ibc/pdf/coppens/fruits\%20 from\%20 America/co.

Ihekoronye, A.I., Ngoddy, P.O. 1985. Integrated Food Science and Technology for the Tropics, $1^{\text {st }}$ edition, Macmillan Publishers Ltd., London, UK.

Larmond, E. 1982. Laboratory Methods for Sensory Evaluation of Food, Publication No. 1637, Department of Agriculture Canada.

Medina J.D.L.C., Garcia, H.S. 2005. Chapter 33 Pineapple. Post-Harvest Operation. www. cms.cnr.

Montero-Calderon, M., Rojas-Grau, M.A., MartinBelloso, O. 2008. Effect of packaging conditions on quality and shelf life of fresh-cut pineapple (Ananas comosus). Postharvest Biology and Technology, 50: 182-189.

Mundogar, 2004. htpp:/www.mundogar.com.

Nelson, K.A. 2005. Photochemically Induced Flavour Changes in Orange Juice Exposed to Light in Glass and Polyethylene Terephthalate at $4{ }^{\circ} \mathrm{C}$. MS. Thesis, Graduate School of the University of Florida, USA.

Takahashi, H., Inada, Y., Mori, D., Tatsuka, K. 2000. Changes in volatile constituents of Satsuma mandarin oranges during canning and storage of the products. Kenkyu Hokokusho-Tyo shokuhim kogyo Tanki Daigaku, Toyo shokulim kenkyusho, 23: 57-64.

Verma, L.R., Joshi, V.K. 2000. Postharvest Technology of Fruits and Vegetables Handling, Processing, vol. 2, pp. 244-247, Indus Publishing Co., New Delhi, India. 